Article

\title{
Preparation and Identification of Novel Antihypertensive Peptides from the In Vitro Gastrointestinal Digestion of Marine Cobia Skin Hydrolysates
}

\author{
Yu-Hsin Lin ${ }^{1}$, Chun-An Chen ${ }^{2}$, Jenn-Shou Tsai ${ }^{2}$ and Guan-Wen Chen ${ }^{2, *}$ (i) \\ 1 Department of Food Technology and Marketing, Taipei University of Marine Technology, No. 212, Section 9, \\ Yan Ping North Road, Taipei 111, Taiwan; yhlin@mail.tumt.edu.tw \\ 2 Department of Food Science, National Taiwan Ocean University, No. 2 Pei-Ning Road, Keelung 202, Taiwan; \\ anguschen823@gmail.com (C.-A.C.); tsaijs@mail.ntou.edu.tw (J.-S.T.) \\ * Correspondence: chengw@mail.ntou.edu.tw; Tel.: +886-2-2462-2192 (ext. 5135)
}

Received: 4 May 2019; Accepted: 13 June 2019; Published: 15 June 2019

\begin{abstract}
This research focuses on cobia skin hydrolysates and their antihypertensive effects via the inhibitory activities of angiotensin I-converting enzyme (ACE). Marine fish Cobia (Rachycentron canadum) skin was hydrolysed for $5 \mathrm{~h}$ using Protamex and Protease $\mathrm{N}$ to obtain the cobia skin protein hydrolysates PX-5 and PN-5, respectively. The soluble protein and peptide contents of the PX-5 were 612 and $270 \mathrm{mg} / \mathrm{g}$, respectively, and for the PN-5, 531 and $400 \mathrm{mg} / \mathrm{g}$, respectively. The IC 50 of PX-5 and PN-5 on ACE was 0.221 and $0.291 \mathrm{mg} / \mathrm{mL}$, respectively. Increasing the $\mathrm{IC}_{50}$ from 0.221 to $0.044 \mathrm{mg} / \mathrm{mL}$ by simulated gastrointestinal digestion (PX-5G) reduced the ACE-inhibitory capacity of PX-5. Using gel filtration chromatography, the PX-5G was fractioned into eight fractions. The molecular weight of the fifth fraction from PX-5G was between 630 and $450 \mathrm{Da}$, and the highest inhibitory efficiency ratio on ACE was $1552.4 \% / \mathrm{mg} / \mathrm{mL}$. We identified four peptide sequences: Trp-Ala-Ala, Ala-Trp-Trp, Ile-Trp-Trp, and Trp-Leu, with IC 50 values for ACE of 118.50, 9.40, 0.51, and $26.80 \mu \mathrm{M}$, respectively. At a dose of $600 \mathrm{mg}$ PX-5 powder/kg body weight, in spontaneously hypertensive rats PX-5's antihypertensive effect significantly reduced systolic and diastolic blood pressure by 21.9 and 15.5 $\mathrm{mm} \mathrm{Hg}$, respectively, after $4 \mathrm{~h}$ of oral gavage.
\end{abstract}

Keywords: marine fish cobia; gastrointestinal digestion; inhibitory efficiency ratio; systolic blood pressure

\section{Introduction}

Globally, cardiovascular disease is a leading cause of death. Hypertension is a major risk factor for cardiovascular disease. The World Health Organization predicts that in 2020, stroke and heart disease will surpass infectious diseases as a cause of death [1]. One approach to addressing hypertension is the use of synthetic drugs to inhibit the activity of angiotensin I-converting enzyme (ACE). ACE is a key enzyme that regulate blood pressure in the human renin-angiotensin system. In medical operations ACE inhibitory drugs such as Capoten, Vasotec, and Aceon [2] are commonly used. These are largely short-chain peptide derivatives with verified effectiveness [3]. However, their side-effects may include dizziness, coughing, and allergic reactions [4]. Therefore, bioactive natural substances for inhibiting ACE functions are being explored.

ACE-inhibitory peptides have been the target of research in the last decade. These are produced via protease-hydrolysed food proteins. Researchers have obtained ACE inhibitory peptides from foods [5] such as fermented milk [6-8], shellfish [9,10], chicken [11], eggs [12-16], mushrooms [17], 
chlorella [18-20], fish [21,22], and fish scales and skin [23,24]. Gelatin extracted from the skin of squid has been hydrolysed by pepsin to produce ACE-inhibitory peptides. In the gelatin hydrolysates of the squid skin, a fraction with a desired low molecular weight (MW) peptide of less than $2 \mathrm{kDa}$ revealed the strongest inhibitory capacity on $\mathrm{ACE}$, with an $\mathrm{IC}_{50}$ value of $0.33 \mathrm{mg} / \mathrm{mL}$. Oral gastric intubation was then used to administer the collected fraction to a rat model of renovascular hypertension (RHR). After 30 days, the fraction had a significant effect on blood-pressure reduction [25]. In another study, squid skin collagen was processed to yield the protein hydrolysates and then further hydrolysed by gastrointestinal proteases. Within the hydrolysate fractions, the strongest inhibitory capacity on ACE was exhibited by a low MW collected fraction $(<1 \mathrm{kDa})$. After further isolation and sequence analysis of this collected fraction, its peptide sequence was revealed to be G-R-G-S-V-P-A-Hyp-G-P, which had an $\mathrm{IC}_{50}$ of $47.78 \mu \mathrm{M}$ [26]. Gelatin extracted from Pacific cod (Gadus microcephalus) skin has been hydrolysed using gastrointestinal proteases, and commercial enzymes. Pacific cod skin gelatin hydrolysates $(<1 \mathrm{kDa})$ by gastrointestinal proteases hydrolysis that produced two strong ACE inhibitory peptides were G-A-S-S-G-M-P-G and L-A-Y-A, which had IC $\mathrm{IC}_{50}$ values of 6.9 and $14.5 \mu \mathrm{M}$, respectively [27]. Cobia (R. canadum) head protein hydrolysate (CHPH) with an ACE-inhibitory effect has been prepared using papain. In the hydrolysate, a collected fraction with a low $\mathrm{MW}$ below $<3 \mathrm{kDa}$ (CHPH-IV) exhibited a reduced $\mathrm{ACE} \mathrm{IC}_{50}$ value of $0.17 \mathrm{mg} / \mathrm{mL}$ (from $0.24 \mathrm{mg} / \mathrm{mL}$ ) after hydrolysis in digestive enzymes. Spontaneously hypertensive rats (SHR) exhibited a significant dose-dependent reduction in blood pressure of after oral gastric intubation with CHPH-IV for $4 \mathrm{~h}$ at dose levels of 150, 600 , and $1200 \mathrm{mg} / \mathrm{kg}$ body weight (BW) [28].

Cobia is a member of the Rachycentridae, a family of large predatory, pelagic oceanic fish. Except for the Eastern Pacific, it is primarily a denizen of tropical and subtropical waters [29], and is among the most commonly farmed fish in Penghu and Pingtung Counties, Taiwan [30]. In 2017, the production of cobia was 1615 metric tons, and its output value was NT\$624.6 million [31]. Fresh cobia is usually served as sashimi or exported, but fillet production leaves numerous byproducts such as the head, liver, fin, and frame, roughly $40-50 \%$ of the fish by body weight [32]. In addition, more than $50 \%$ of byproducts of marine fish cobia are considered as waste after fishing and processing, so about 3.2 million tons of waste each year cause environmental pollution [33]. The fish skin and belly are used in salads and thus have relatively low economic value. The protein content of cobia skin is approximately 30\%, making it an ideal candidate for developing functional foods that could add value to the cobia farming process.

Fish byproducts are highly nutritious and safe food ingredients [34] that can be used to produce foods and medicines, making them a crucial biological resource. Enzymes have been used to hydrolyse fish byproducts and prepare peptides with bioactivity $[24,35,36]$. Studies investigating the antioxidant and antihypertensive activities of compounds exhibiting bioactivity and peptides beneficial to health in fish skin and bone have attracted public interest [37-39]. However, little is known about the ACE-inhibitory activity and antihypertensive effects of protein hydrolysate from cobia skin. Because of the large quantities of proteins in cobia skin, bioactive peptides produced by protease hydrolysis of cobia skin are of great significances. Thus, to compare the efficacy of the hydrolysates, the current study measures the inhibitory effects of cobia skin protein waste on ACE. Simulated gastrointestinal digestion was used to measure the stability of the hydrolysates' ACE-inhibitory effects. Furthermore, the major ACE inhibitory peptides of hydrolysates were purified and identified to confirm their peptide sequences. Short-term hypotensive effect of bioactive substance was then evaluated using SHRs as animal model.

\section{Materials and Methods}

\subsection{Materials}

R. canadum was purchased from Tan Hou Ocean Development Co. (Penghu, Taiwan), Taipei. Protamex (a mixture of endo and exopeptidase from Bacillus sp., activity labelled $1.5 \mathrm{AU} / \mathrm{g}$ ) and 
Protease N (a mixture of endo and exopeptidase from Bacillus subtilis, activity labelled 150,000 U/g) were respectively obtained from Novo Nordisk A/S Co. (Bagsværd, Denmark) and Amano Pharmaceutical Co. (Yokohama, Kanagawa, Japan). Enzymes including pepsin, pancreatin and rabbit lung ACE were purchased from Sigma Chemical Co. (St. Louis, MO, USA). Substrate (hippuryl-L-histidyl-L-leucine, HHL) and all chemicals used were of analytical grade and also purchased from Sigma Chemical Co. (St. Louis, MO, USA).

\subsection{Preparation of Hydrolysates of Cobia Skin}

The cobia skin was immersed in boiling water $\left(98 \pm 2{ }^{\circ} \mathrm{C}\right)$ for $10 \mathrm{~s}$ and then cooled in cold water $\left(4{ }^{\circ} \mathrm{C}\right)$ for $1 \mathrm{~min}$, scales and remaining flesh were removed with a spoon. The skin was homogenised using a Blixer-3 (Robot Coupe Inc., (Ridgeland, MS, USA) at a high speed for $30 \mathrm{~s}$, placed in a polyethylene bag, and stored at $-20^{\circ} \mathrm{C}$. A total of $150 \mathrm{~g}$ of the blended fish skin was prepared and uniformly mixed with 6 times $(w / w)$ deionized water containing with $1.35 \mathrm{~g}$ of commercial protease (Protamex or Protease N); the amount of protease added to the blended fish skin was 3\% $(w / w)$ of the fish-skin crude protein $(30 \%)$. The mixture was left to hydrolyse at $50{ }^{\circ} \mathrm{C}$ in thermostatically water controlled water bath for $5 \mathrm{~h}$. After hydrolysis, the mixture was immersed in a boiling water bath for $10 \mathrm{~min}$ to deactivate the protease and then cooled to room temperature in a cold water bath. The hydrolysate was filtered twice through even layers of diatomaceous earth placed evenly on Advantec No. 2 filter paper (Toyo Roshi Kaisha, Ltd., Tokyo, Japan). The clear translucent hydrolysate was freeze dried in Labconco freeze drying system (Labconco, AST Instruments Corporation, Kansas, KS, USA) to yield a powder for subsequent analysis.

\subsection{Biochemical Analysis}

The method developed by Folin-Lowry [40,41], was used to determine the content of soluble protein in the cobia fish skin hydrolysates, the standard used was albumin from bovine serum. One $\mathrm{mL}$ of copper analytical reagent (alkaline) was added as well as $3.0 \mathrm{~mL}$ of a 1:10 dilution of Folin-Ciocalteu reagent (Merck, KGaA, Darmstadt, Germany). Incubation was allowed to proceed for $30 \mathrm{~min}$ at room temperature. A Shimadzu UV spectrometer (Kyoto, Japan) was used to measure absorbance at $540 \mathrm{~nm}$.

\subsection{Determination of Peptides}

A slightly modified procedure, developed by Church et al. [20,42], was used to measure the sample peptide content. A hydrolysate solution with a concentration of $30 \mathrm{mg} / \mathrm{mL}$ was passed through a $0.22-\mu \mathrm{m}$ membrane before ultra-filtration at 5-kDa MW cut-off (MWCO). Fifty milliliter was mixed with $2.0 \mathrm{~mL}$ of $o$-phthaldialdehyde at room temperature and allowed to stand for $2 \mathrm{~min}$. A Shimadzu UV-160A (Kyoto, Japan) was used to measure absorbance at $340 \mathrm{~nm}$. The peptide content was quantified using Leu-Gly (Sigma, St. Louis, MO, USA) as a standard.

\subsection{Measurement of Free Amino Acid Content}

The free amino acid content of the sample was determined using a slight modifications of previously published methods [6,43]. A total of $0.5 \mathrm{~mL}$ of the protein hydrolysate was mixed with $1.0 \mathrm{~mL}$ of $\mathrm{Cd}$-ninhydrin solution $(0.8 \mathrm{~g}$ of ninhydrin dissolved in a mixture of $80 \mathrm{~mL} 99.5 \%$ ethanol and $10-\mathrm{mL}$ acetic acid combined with $1.0 \mathrm{~g}$ of $\mathrm{CdCl}_{2}$ dissolved in $1.0 \mathrm{~mL}$ of deionized water). After addition of the sample the screw capped tube was rapidly transferred to a water bath at $84{ }^{\circ} \mathrm{C}$ for $5 \mathrm{~min}$. After cooling to $25^{\circ} \mathrm{C}$, the absorbance was measured at $507 \mathrm{~nm}$ with a UV-160A spectrophotometer (Shimadzu, Kyoto, Japan). The free amino acid content was quantified using L-Leucine as a standard.

\subsection{ACE Inhibition Assay}

RP-HPLC was used to measure ACE inhibition by means of a method devised by Cushman and Cheung [44,45]. The sample consisted of $15 \mathrm{mM} \mathrm{HHL}$ in Na-borate buffer $(100 \mathrm{mM}, \mathrm{pH} \mathrm{8.3)}$ 
plus $\mathrm{NaCl}(300 \mathrm{mM})$. Rabbit lung ACE, also in Na-borate buffer, was added to a concentration of $53.2 \mathrm{mU} / \mathrm{mL}$. Equal volumes $(75 \mu \mathrm{L})$ of the ACE solution and samples passed through a 5-kDa MWCO membrane were then incubated for $10 \mathrm{~min}$ at $37^{\circ} \mathrm{C}$. Seventy-five milliliter of the solution of HHL was then added and incubation was continued for a further $30 \mathrm{~min} .1 .0 \mathrm{~N} \mathrm{HCl}(250 \mu \mathrm{L})$ was used to stop the reaction and $10 \mu \mathrm{L}$ was injected into a Luna $C_{18}$ column. The column used to separate the HHL substrate from the HA (hippuric acid) released by ACE action was a Phenomenex $5 \mu \mathrm{m}$ $\left(4.6 \times 250 \mathrm{~mm}^{2}\right)$. Elution of the column was done using 50:50 (v/v) methanol-0.1\% trifluoroacetic acid at a constant flow rate of $0.8 \mathrm{~mL} / \mathrm{min}$ using a Hitachi L-7100 pump (Tokyo, Japan) and monitored at $228 \mathrm{~nm}$ by a spectrophotometer using a UV-VIS 118 Gilson detector (Villiers-le-Bel, France). Finally, inhibition activity was calculated using the following formula:

$$
\text { Inhibition activity }(\%)=((E c-E s) /(E c-E b)) \times 100
$$

where Ec is the absorbance when the buffer was added as control, Es is the absorbance when the sample was added to the reaction mixture (sample), and $\mathrm{Eb}$ is the absorbance when the stop solution was added before the reaction occurred (blank). The $\mathrm{IC}_{50}$ value was defined as the peptide concentration $(\mathrm{mg} / \mathrm{mL})$ required to reduce $50 \%$ of the height of the HA peak (50\% ACE inhibition) Evaluation of the $\mathrm{IC}_{50}$ was done using regression analysis of the ACE inhibition activity (\%) against the $\log _{10}$ concentration $(\mathrm{mg} / \mathrm{mL})$ of the sample peptide. Captopril, used as a positive control, had significantly high ACE inhibition activity $\left(\mathrm{IC}_{50}=0.0069 \mu \mathrm{M}\right)$. The data used in this study were all averages of three readings or standard deviations (SDs).

\subsection{In Vitro Gastrointestinal Digestion}

In vitro digestion simulation was done using slight modifications of a previously published method [45]. The control used was 3.5\% PX-5 (w/v) (hydrolysate from Protamex hydrolysis for $5 \mathrm{~h}$ ) in $0.1 \mathrm{M} \mathrm{KCl}-\mathrm{HCl}$ buffer (at $\mathrm{pH} 2.0$ ) plus pepsin (1:25) incubation was carried out at $37^{\circ} \mathrm{C}$ for four hours. The reaction was stopped by immersing the reaction vessel in boiling water for ten minutes. $\mathrm{NaOH}(2 \mathrm{M})$ was used to neutralize the mixture and $50 \mathrm{~mL}$ was spun at $10,000 \times g$, for thirty minutes. The supernatant $(2 \mathrm{~mL})$ was analysed for ACE inhibition activity. The rest of the suspension was digested with pancreatin at 1:25 (w/w) for four hours at $37^{\circ} \mathrm{C}$. The vessel was immersed in boiling water for ten minutes to stop the reaction. The suspension was spun at $10,000 \times g$ for thirty minutes. Some of the supernatant was analysed for ACE inhibition and the rest was freeze dried to give PX-5G for later purification and analysis of ACE inhibition.

\subsection{Gel Filtration}

The hydrolysate of PX-5G had the highest ACE inhibition and was purified using Sephadex (G-25, $1.6 \times 90 \mathrm{~cm}^{2}$; Amersham Pharmacia Biotech AB, Uppsala, Sweden) in a gel filtration process and $0.02 \% \mathrm{NaN}_{3}$ in deionized water was used for equilibration. Three hundred milligram of hydrolysate in $10 \mathrm{~mL}$ of deionized water was filtered using a 5-kDa MWCO membrane and $2.0 \mathrm{~mL}$ of filtrate was injected into the Sephadex G-25 column (Amersham Pharmacia Biotech AB, Uppsala, Sweden) and eluted with $0.02 \% \mathrm{NaN}_{3}$ at $0.5 \mathrm{~mL} / \mathrm{min}$. 5-mL fractions were collected, and the absorbance of each fraction was determined at $280 \mathrm{~nm}$. The standards (Bacitracin, penta-L-phenylalanine and tryptophan) used for calibration of the Sephadex G-25 and their molecular weight were $1422 \mathrm{Da}, 753.9$ and 204.2 Da, respectively.

\subsection{Isolation of Bioactive Peptides with ACE-Inhibitory Activity}

A slight modification of the method developed by Chen et al. [6] was used to purify the peptides with ACE inhibitory activity from the hydrolysates. The fraction from the Sephadex gel filtration with the highest ACE-inhibitory activity was collected, lyophilized, and further separated by RP-HPLC (L-7100, Hitachi, (Tokyo, Japan)) using a semi-preparative $C_{18}$ column (Synergi $4 \mu$ m Hydro-RP $80 \AA$, 
$10 \times 250 \mathrm{~mm}^{2}$; Phenomenex, (Torrance, CA, USA)). Solution A and solvent B were $0.1 \%$ trifluoroacetic acid (TFA) in deionized water and acetonitrile solution containing $0.1 \%$ TFA. A gradient from $0 \%$ to $50 \%$ of solvent B was employed, with a sample of $500 \mu \mathrm{L}$, to separate the peaks using a flow of $1.5 \mathrm{~mL} / \mathrm{min}$ over two hours at room temperature. A Gilson $118 \mathrm{UV}-\mathrm{VIS}$ detector and a 715 system controller were used and monitoring was done at $220 \mathrm{~nm}$. Repeated runs were done to collected the individual peaks. Each was tested for purity in the same way as described above using a $4 \mu \mathrm{m}$ Joupiter Proteo (Phenomenex, Torrance, CA, USA) 90^, column, the same solvent, gradient and flow rate over one hour. Monitoring was done during elution at $220 \mathrm{~nm}$. Finally, the peaks were collected and lyophilized to a powder for ACE inhibitory activity assay, and then the peaks demonstrating the highest inhibition of ACE were collected and lyophilized, and their peptide sequences were identified.

\subsection{Identification of Antihypertensive Peptide Sequences}

A slight modification of the method offered by Lin et al. [20,46] was used to determine the peptide sequences. Samples for analysis were prepared as follows: The PX-5G concentration was increased from 30 to $100 \mathrm{mg} / \mathrm{mL}$ and purified by gel filtration chromatography. Fraction E was collected through triplicate chromatography. The collections were combined, lyophilized, and dissolved in $0.5 \mathrm{~mL}$ of deionized water. The resulting solution was further separated by RP-HPLC on a semi-preparative $C_{18}$ column using the method described before. Each peak was collected using quintuplicate chromatography, and then a single component of each peak was confirmed using an analytical $C_{12}$ analytical column by the previously described method. The five collected mixtures were then lyophilized, and their inhibition of ACE activity and peptide sequence was determined. Automated Edman degradation was done using a Procise 492 protein sequencer (Perkin-Elmer Co. Ltd., Applied Biosystem Inc., Foster City, CA, USA) to determine the sequence of amino acids in peptides that showed high ACE inhibition [40]. Finally, the identified ACE-inhibitory peptides were synthesised through solid-phase peptide synthesis. The synthetic peptides were used as the standard for qualitative analysis of these peptides in the cobia skin hydrolysates using an RP-HPLC column (ODS $\mathrm{C}_{12}$ ) by the previously described method. Amino acid sequence alignment of the R. canadum proteins (Secreted protein acidic and cysteine rich, SPARC (accession number: G8XR48), rhodopsin (accession number: T1QSV8), elongation of very long chain fatty acids protein 5 (accession number: B7U6V2), and cytochrome c oxidase subunit 1 (accession number: B5U133)) was done using the UniProt database [47]. Pairwise sequence alignment tools were employed to confirm identical sequences [48].

\subsection{Blood Pressure Measurement}

The scientific research and testing using animals were conducted according to the rules and regulations of the National Taiwan Ocean University, Animal Care and Use Committee, Keelung, under ethical approval certificate number 95,028. Eighteen seven weeks old male SHRs were kept in individual steel cages with a 12-h light and dark cycle. The ambient temperature and relative humidity were $23 \pm 1{ }^{\circ} \mathrm{C}$ and $55 \% \pm 5 \%$. The feed used was Rodent Laboratory 5001 from PMI Nutrition International, Brentwood, MO, USA. The animals had free access to water and were kept for eight weeks before the experiments were started. The fifteen week old SHRs had a body weight of $350 \mathrm{~g} \pm 5 \mathrm{~g}$, systolic blood pressure of $173.0 \pm 4.2 \mathrm{~mm} \mathrm{Hg}$ and diastolic blood pressure of $150.0 \pm 3.7 \mathrm{~mm} \mathrm{Hg}$. In animal studies, the blood pressure was obtained from eighteen rats. The extreme values, including the four highest and four lowest, were excluded. The remaining values were randomly allocated into the control group $(n=5)$ and study group $(n=5)$. A statistical analysis showed no significant difference in the systolic and diastolic pressures of the two groups $(p<0.05)$. This was followed by a short-term rat gavage study to assess the blood pressure changes. Two groups of five rats were selected at random and one group received gastric intubation of PX-5 dissolved in $2 \mathrm{~mL}$ of saline at a dose rate of $210 \mathrm{mg}$ per $350 \mathrm{~g}$ BW (56.7 mg peptide/rat BW). The second group of five received equal volumes of normal saline. The systolic blood pressure (SBP) and diastolic blood pressure (DBP) of the animals was measured at two hourly intervals for eight hours and then at $24 \mathrm{~h}$ after dosage. Each animal was 
placed in a box controlled at $45^{\circ} \mathrm{C}$ for $5 \mathrm{~min}$ before blood pressure and heart rate measurements were made. A noninvasive method, BP-98, Softron, Tokyo, Japan, was used with a tail-cuff. The results are shown as means \pm SDs.

\subsection{Statistical Data Treatment}

Changes in blood pressure were determined as the difference between systole and diastole before/after dosage with $56.7 \mathrm{mg}$ of peptide/rat BW of PX-5 (data expressed as mean \pm SD). The analytical results of the cobia skin hydrolysates obtained by gel column size exclusion and RP-HPLC are averages of the measurement of 3 samples. All statistical analyses were carried out using SAS (version 9.4 TS1M5; SAS Institute Inc., Carry, NC, USA). The $p$-value less than 0.05 was considered statistically significant. SAS was used for the analysis of variance calculations using the general linear procedure [49]. SAS was also used for Duncan's multiple range multiple mean test comparisons.

\section{Results and Discussion}

\subsection{IC $_{50}$ and Soluble Protein, Peptide, and Free Amino Acid Contents}

The scales and residual flesh on a cobia skin sample were removed and it was hydrolysed using protease, specifically Protamex and Protease N, for $5 \mathrm{~h}$ to give hydrolysates PX-5 and PN-5. The chemical compositions (soluble protein, peptide, and free amino acid contents) as well as ACE IC50 of the hydrolysates were subsequently determined (Table 1). In this study cobia skin was hydrolysed for $2 \mathrm{~h}$ (data not shown) and $5 \mathrm{~h}$ with Protamex and Protease $\mathrm{N}$ and then determined their contents of soluble proteins, peptides and free amines. In the 2-h and 5-h hydrosylate with Protamex, the levels of soluble proteins are $555.0 \pm 4.0$ and $612.0 \pm 9.0 \mathrm{mg} / \mathrm{g}$, respectively, and the levels of peptides are $180.0 \pm 3.0$ and $270.0 \pm 7.0 \mathrm{mg} / \mathrm{g}$, respectively. For the Protease $\mathrm{N}$ group, the levels of soluble proteins are $498.0 \pm 5.0$ and $531.0 \pm 7.0 \mathrm{mg} / \mathrm{g}$, respectively, and the levels of peptides are $258 \pm 6.0$ and $400.0 \pm 9.0 \mathrm{mg} / \mathrm{g}$, respectively. When hydrolysed by these proteases, the level of each composition increases with time. This result is similar to the changes of composition level seen in the hydrosylates obtained by treating clam flesh with Protamex [50]. With longer treatment time, larger protein molecules are hydrolysed, thus the levels of soluble proteins and peptides increase. In addition, the results showed that protein hydrolysate PX-5 (612 mg/g) contained a higher soluble protein content than did PN-5 (531 mg/g). By contrast, PN-5 had higher peptide and free amino acid contents than did PX-5, with the peptide content of PN-5 (400 mg/g) being 1.5 times that of PX-5 $(270 \mathrm{mg} / \mathrm{g})$. The ACE-inhibitory activity of PX-5 $\left(\mathrm{IC}_{50}=0.221 \mathrm{mg} / \mathrm{mL}\right)$ was higher than that of PN-5 $\left(\mathrm{IC}_{50}=0.291 \mathrm{mg} / \mathrm{mL}\right)$.

Table 1. Chemical compositions and $\mathrm{ACE} \mathrm{IC}_{50}$ of cobia skin protein hydrolysates.

\begin{tabular}{ccccc}
\hline Sample & $\begin{array}{c}\text { Soluble Protein } \\
(\mathbf{m g} / \mathbf{g})\end{array}$ & $\begin{array}{c}\text { Peptide Content } \\
(\mathbf{m g} / \mathbf{g})\end{array}$ & $\begin{array}{c}\text { Free Amino Acid } \\
(\mathbf{m g} / \mathbf{g})\end{array}$ & $\begin{array}{c}\mathrm{IC}_{\mathbf{5 0}} \mathbf{1}^{\mathbf{1}} \\
(\mathbf{m g} / \mathbf{m L})\end{array}$ \\
\hline $\mathrm{PX}^{-2} 5^{2}$ & $612.0 \pm 9.0^{\mathrm{b}}$ & $270.0 \pm 7.0^{\mathrm{a}}$ & $75.5 \pm 0.2^{\mathrm{a}}$ & $0.221 \pm 0.005^{\mathrm{a}}$ \\
$\mathrm{PN}^{3} 5^{3}$ & $531.0 \pm 7.0^{\mathrm{a}}$ & $400.0 \pm 9.0^{\mathrm{b}}$ & $97.3 \pm 0.8^{\mathrm{b}}$ & $0.291 \pm 0.005^{\mathrm{b}}$ \\
\hline
\end{tabular}

Values are averages of three measurements. Superscripts in the columns signify notable differences between values. ${ }^{1}$ Amount that will inhibit ACE activity by $50 \%$. ${ }^{2}$ PX-5 was produced from Protamex (3\%) hydrolysis for $5 \mathrm{~h} .{ }^{3}$ PN-5 from five hours protease $\mathrm{N}(3 \%)$ hydrolysis.

\subsection{Antihypertensive Effect of Cobia Skin Protein Hydrolysate}

PX-5 (56.7 mg of peptide/350 g BW) was given to SHRs over a short term. This was the equivalent of $350 \mathrm{~g}$-equivalent to $600 \mathrm{mg}$ powder $/ \mathrm{kg}$ BW/rat. Because of its negligible effect on SBP, saline was used as a control. PX-5 administration caused a significant decrease in SBP after 2 to $8 \mathrm{~h}$ which reverted to the original level after $24 \mathrm{~h}$. SBP in the SHRs that had received the peptide was $21.9 \mathrm{~mm} \mathrm{Hg}$ lower 
than that of the controls $4 \mathrm{~h}$ after feeding. For DBP the values in both experimental groups was 15.5 $\mathrm{mm} \mathrm{Hg}$ lower than in the controls, see Figure 1.

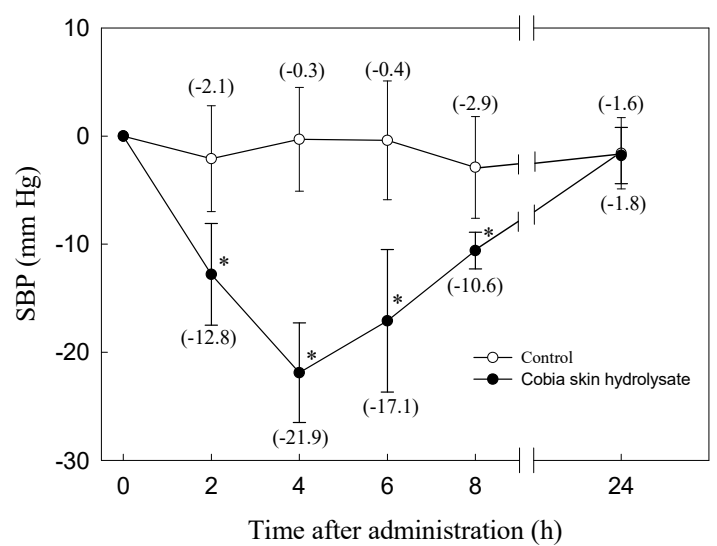

a

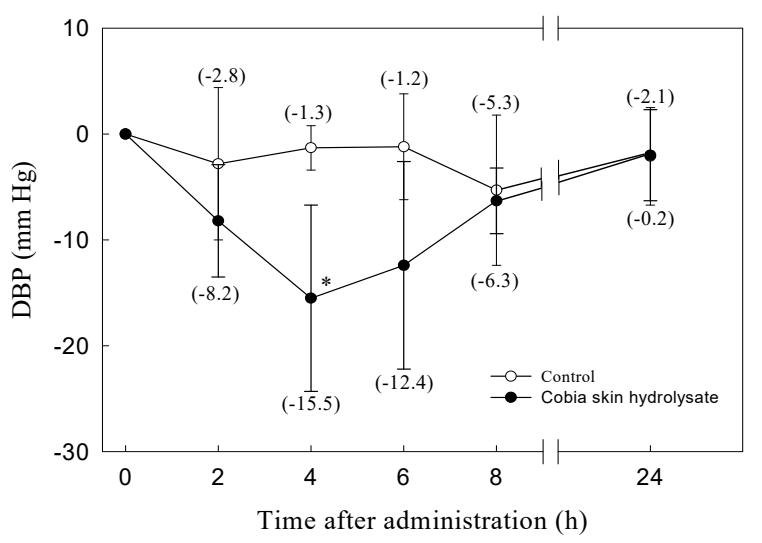

b

Figure 1. The effect of oral administration of PX-5 on blood pressure in SHRs. (a) systolic blood pressure (SBP); (b) diastolic blood pressure (DBP). $-\bigcirc-$, control $=0.9 \% \mathrm{NaCl}$ in deionized water;

- -, $210 \mathrm{mg}$ of hydrolysate in $0.9 \% \mathrm{NaCl}$; Each value is a mean of five readings. The bars indicate standard error. *: significant difference from control, $p<0.05$.

Other reports about cobia protein hydrolysates [28], such as CHPH-IV extracted from cobia head protein hydrolysate by papain, showed strong antihypertensive action in SHRs. At dosages of 150, 600, and $1200 \mathrm{mg}$ of hydrolysate/kg BW, SBP decreases of about 30, 35 and $57 \mathrm{~mm} \mathrm{Hg}$ were observed four hours after dosing. Tofuyo also showed strong antihypertensive action. SHRs fed a diet containing lyophilized tofuyo for 6 weeks, showed an SBP decrease of $8 \mathrm{~mm} \mathrm{Hg}$. The major ACE-inhibitory peptide separated from tofuyo is Trp-Leu [51]. Other studies have revealed the experimental results of feeding unique tryptophan-containing peptides to humans. Baseline plasma concentrations of the Trp-Leu peptide measured after oral administration of $100 \mathrm{mg}$ Trp-Leu to human volunteers were reported in detail by Kaiser et al. [52]. The maximum plasma concentrations of Trp-Leu were approximately $29-36 \mathrm{pmol} / \mathrm{mL}$ after $30 \mathrm{~min}$, with ACE activity in plasma decreasing by $16-22 \%$ at $1.5 \mathrm{~h} \mathrm{[52].} \mathrm{These} \mathrm{results} \mathrm{showed} \mathrm{Trp-Leu} \mathrm{is} \mathrm{resistant} \mathrm{to} \mathrm{enzymatic} \mathrm{hydrolysis} \mathrm{in} \mathrm{the} \mathrm{stomach} \mathrm{and}$ intestines and can enter the blood circulatory system. These results can serve as a reference for our future research.

\subsection{In Vitro Digestive Stability and ACE inhibition of the Cobia Skin Hydrolysates}

Simulated gastric digestion in vitro was considered a useful and simple method to determine the degree of resistance of these ACE-inhibitory peptides to degradation. The ACE-inhibitory activity of both PX-5 and PN-5 were decreased significantly by simulated gastrointestinal (pepsin-pancreatin) hydrolysis. The $\mathrm{IC}_{50}$ values increased from 0.221 to $0.304 \mathrm{mg}$ peptide/ $\mathrm{mL}$ and that of PN-5 from 0.291 to $0.384 \mathrm{mg}$ peptide/mL (see Table 2). While hydrosylates PX-5 and PN-5 showed reduced ACE inhibition from the hydrolytic activity of digestive enzymes, PX-5 still showed better ACE inhibition than PN-5. Therefore, PX-5 was chosen for the peptide purification and identification analysis. In another study the ACE inhibition effects of Chlorella sorokiniana peptides went down after simulated gastrointestinal digestion, and the $\mathrm{IC}_{50}$ rose from 0.035 to $0.044 \mathrm{mg}$ peptide/mL [20]. In addition, the major peptide inhibitor of ACE produced from Manchego cheese through separation and identification was sequenced as Val-Arg-Tyr-Leu, corresponding to the $\alpha_{S 2}$-casein fragment $\mathrm{f}(205-208)$. This peptide was further hydrolysed with gastrointestinal proteases, after which its $\mathrm{IC}_{50}$ value raised from 0.009 to $0.03 \mathrm{mg} / \mathrm{mL}$. However, the ACE-inhibitory capacity decreased because the hydrophobic amino acid leucine at the C-terminus of Val-Arg-Tyr-Leu underwent hydrolysis and generated Val-Arg-Tyr [53]. 
Table 2. ACE activity inhibition of PX-5 and PN-5 obtained from gastrointestinal protease hydrolysis.

\begin{tabular}{ccc}
\hline Sample & Protease & IC $_{50}(\mathrm{mg} / \mathrm{mL})$ \\
\hline PX-5 & Control & $0.221 \pm 0.005^{\mathrm{b}}$ \\
& PX-5P $^{1}$ & $0.217 \pm 0.005^{\mathrm{b}}$ \\
PN-5 & PX-5G $^{2}$ & $0.304 \pm 0.005^{\mathrm{a}}$ \\
& Control $^{\mathrm{P}}$ & $0.291 \pm 0.005^{\mathrm{c}}$ \\
& PN-5P $^{1}$ & $0.308 \pm 0.003^{\mathrm{b}}$ \\
& PN-5G $^{2}$ & $0.384 \pm 0.002^{\mathrm{a}}$ \\
\hline
\end{tabular}

Values are averages of three measurements. Superscripts in the columns signify notable differences between values.

${ }^{1}$ Four hours pepsin hydrolysis. ${ }^{2}$ Four hours pancreatin hydrolysis after four hours of pepsin hydrolysis.

\subsection{Separation and Assessment of Potent ACE-Inhibitory Peptides}

In this study, the ACE-inhibitory capacity of PX-5 decreased (the $\mathrm{IC}_{50}$ value rose from 0.221 to $0.304 \mathrm{mg} / \mathrm{mL}$ ) after enzymatic hydrolysis in the stomach and intestines. This result suggests that proteases present in the stomach and intestine can hydrolyse the peptide sequences of ACE-inhibitory activity in PX-5 mixtures. PX-5 after digestion by gastrointestinal proteases (PX-5G) was selected for the purification and identification of possible ACE-inhibitory peptides obtained from the in vitro model simulating gastric digestion, we selected PX-5G to conduct purification and identification. The MW distribution of the ACE-inhibitory peptides in PX-5G was separated by size exclusion chromatography on a Sephadex G-25 column. Eight fractions were separated with MWs ranging from 1670 to $160 \mathrm{Da}$, and were designated A-H (see Figure 2).

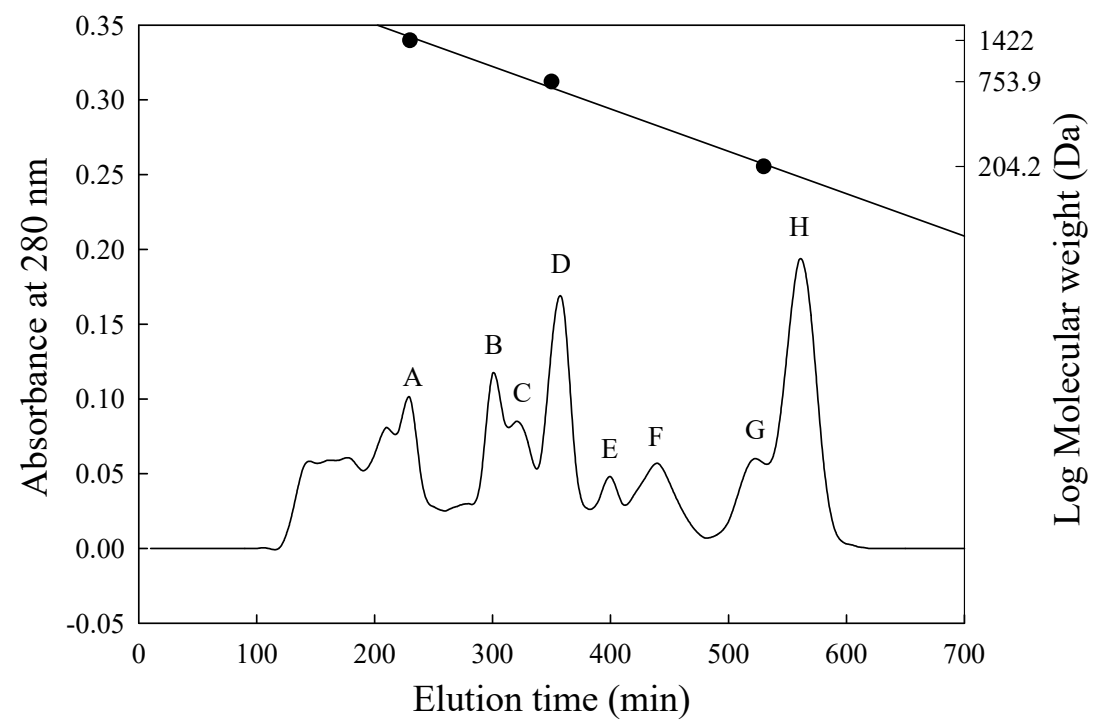

Figure 2. Peptides separate from PX-5G on a Sephadex G-25 column. - Standards: The MWs of Bacitracin, penta-L-phenylalanine and L-tryptophan were 1422, 753.9 and 204.2 Da, respectively. PX-5G was separated into 8 fractions designated as $\mathrm{A}-\mathrm{H}$.

The concentration of peptide in fractions A-H were $0.706,1.190,0.820,0.397,0.042,0.028,0.083$, and $0.022 \mathrm{mg} / \mathrm{mL}$, respectively (Table 3). In spite of fraction A had the strongest ACE-inhibitory percentage, the data for effective ACE inhibition (inhibitory efficiency ratio (IER) = inhibition (\%)/peptide concentration $(\mathrm{mg} / \mathrm{mL})$ ) indicated that the peptide fraction $\mathrm{E}$ showed a higher rate of inhibition than any from the other peaks. Specifically, the IER was $1553 \%$ per $\mathrm{mg} / \mathrm{mL}$ (Table 3), and its $\mathrm{IC}_{50}$ value for ACE was $0.020 \mathrm{mg} / \mathrm{mL}$ (data not shown). The highest ACE-inhibitory activity was similar to that of the potent inhibitory tripeptides from the skin of Theragra chalcogramma, Salmo salar or Oncorhynchus keta $[24,54,55]$. According to previous research, many bioactive peptides with ACE-inhibitory activities are short peptide sequences and consisted of 2-12 amino acid residues [56]. 
Table 3. ACE $\mathrm{IC}_{50}$ values of fractions obtained by size exclusion chromatography from PX-5 after gastrointestinal digestion.

\begin{tabular}{ccccc}
\hline Fraction & $\begin{array}{c}\text { Molecular Weight } \\
\mathbf{( D a )}\end{array}$ & $\begin{array}{c}\text { Inhibition } \\
\mathbf{( \% )}\end{array}$ & $\begin{array}{c}\text { Peptide Content } \\
\mathbf{( m g / m L )}\end{array}$ & $\begin{array}{c}\text { IER }^{\mathbf{1}} \\
\mathbf{( \% / m g / m L )}\end{array}$ \\
\hline $\mathrm{A}$ & $1670-1370$ & 72.3 & 0.706 & 102.4 \\
$\mathrm{~B}$ & $1130-870$ & 56.5 & 1.190 & 47.5 \\
$\mathrm{C}$ & $870-760$ & 71.8 & 0.820 & 87.6 \\
$\mathrm{D}$ & $760-630$ & 57.2 & 0.397 & 144.1 \\
$\mathrm{E}$ & $630-450$ & 65.2 & 0.042 & 1552.4 \\
$\mathrm{~F}$ & $450-350$ & 34.0 & 0.028 & 1214.3 \\
$\mathrm{G}$ & $270-220$ & 22.2 & 0.083 & 267.5 \\
$\mathrm{H}$ & $210-160$ & 22.2 & 0.022 & 1009.1 \\
\hline \multicolumn{4}{c}{}
\end{tabular}

Values are averages of three measurements. ${ }^{1}$ IER inhibitory efficiency ratio.

In the present study, the most active peptide of fraction $\mathrm{E}$ was further purified on an RP-HPLC column (ODS $\mathrm{C}_{18}$ ). Figure 3 shows the elution profiles of the peptides. Nine major individual substances were collected using repetitive runs using an RP-HPLC $C_{12}$ column and the same elution gradient as before. Each individual peak was found to be from a single component. Of the nine bioactive substances that had been found, it was determined from the IERs that bioactive substances $\mathrm{E}_{6}, \mathrm{E}_{7}, \mathrm{E}_{8}$, and $\mathrm{E}_{9}$ showed strong ACE inhibition activity with IERs of: $872.9 \%, 1398.3 \%, 3335.7 \%$, and $3021.4 \%$ per $\mathrm{mg} / \mathrm{mL}$, respectively, see Table 4 . These four peaks were collected, lyophilized, and their peptide sequences were determined.

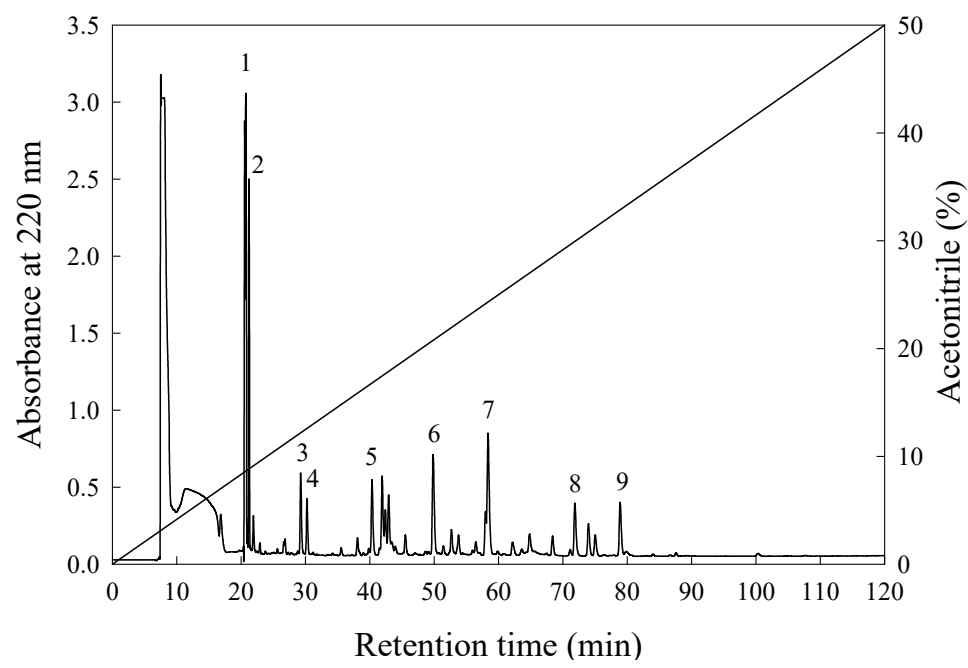

Figure 3. An elution profile analysis of fraction E from PX-5G by RP-HPLC.

Table 4. Isolation of bioactive substances from Figure 2 and their ACE IER analysis.

\begin{tabular}{|c|c|c|c|}
\hline Bioactive Substances & Inhibition (\%) & Peptide Concentration (mg/mL) & $\operatorname{IER}^{1}(\% / \mathrm{mg} / \mathrm{mL})$ \\
\hline $\mathrm{E}_{1}$ & 2.7 & 0.009 & 300.0 \\
\hline$E_{2}$ & 6.5 & $-^{2}$ & -2 \\
\hline$E_{3}$ & 55.6 & 0.073 & 761.6 \\
\hline $\mathrm{E}_{4}$ & 15.3 & 0.109 & 140.4 \\
\hline$E_{5}$ & 7.9 & 0.024 & 329.2 \\
\hline $\mathrm{E}_{6}$ & 41.9 & 0.048 & 872.9 \\
\hline$E_{7}$ & 81.1 & 0.058 & 1398.3 \\
\hline $\mathrm{E}_{8}$ & 93.4 & 0.028 & 3335.7 \\
\hline $\mathrm{E}_{9}$ & 42.3 & 0.014 & 3021.4 \\
\hline
\end{tabular}

Values are averages of three measurements. ${ }^{1}$ IER inhibitory efficiency ratio. ${ }^{2}$ Undetected. 


\subsection{Amino Acid Sequences and ACE-Inhibitory Activity}

The amino acid sequences and $\mathrm{IC}_{50}$ values for the peptides from peaks $\mathrm{E}_{6}, \mathrm{E}_{7}, \mathrm{E}_{8}$, and $\mathrm{E}_{9}$ are shown in Table 5. The peptide sequences were: $\mathrm{E}_{6}-\operatorname{Trp}$-Ala-Ala, $\mathrm{E}_{7} \_$Ala-Trp-Trp, $\mathrm{E}_{8}-$ Ile-Trp-Trp and $\mathrm{E}_{9} \_$Trp-Leu. The $\mathrm{IC}_{50}$ values were: $\mathrm{E}_{6} \_118.50, \mathrm{E}_{7} \_9.40, \mathrm{E}_{8} \_0.51$ and $\mathrm{E}_{9} \_26.80 \mu \mathrm{M}$ this was equivalent to $0.0411,0.00434,0.00026$, and $0.00851 \mathrm{mg} / \mathrm{mL}$, respectively. These isolates were found to belong to the amino acid sequence of SPARC, rhodopsin, elongation of very long chain fatty acids protein 5 , and cytochrome c oxidase subunit 1 , residues $283-285,226-228,153-155$, and 131-132, respectively [47]. Sekiya et al. [57] found that food peptides with ACE inhibition activity that had $\mathrm{IC}_{50}$ value from 100 to $500 \mu \mathrm{M}$ had antihypertensive potential. Overall, it was shown that the ACE inhibition of five of the fractions $\left(E_{2}, E_{6}, E_{7}, E_{8}\right.$, and $\left.E_{9}\right)$ from $\mathrm{PX}-5 \mathrm{G}$ could be raised by purification, either by size exclusion, or RP-HPLC. Cobia skin protein hydrolysates $(0.304 \mathrm{mg} / \mathrm{mL})$ that had not been purified had much higher $\mathrm{IC}_{50}$ values: Fraction E, Trp-Ala-Ala, Ala-Trp-Trp, Ile-Trp-Trp, and Trp-Leu, were respectively about 15, $7,70,1169$, and 35 times lower.

Table 5. Identification of peptide sequences from E6 to E9 peaks and their $\mathrm{ACE} \mathrm{IC}_{50}$ analysis.

\begin{tabular}{cccc}
\hline Peak & Sequence & IC $_{\mathbf{5 0}}(\boldsymbol{\mu M})$ & IC $_{\mathbf{5 0}}(\mathbf{m g} / \mathbf{m L})$ \\
\hline $\mathrm{E}_{6}$ & Trp-Ala-Ala & $118.50 \pm 2.80$ & 0.04110 \\
$\mathrm{E}_{7}$ & Ala-Trp-Trp & $9.40 \pm 0.60$ & 0.00434 \\
$\mathrm{E}_{8}$ & Ile-Trp-Trp & $0.51 \pm 0.10$ & 0.00026 \\
$\mathrm{E}_{9}$ & Trp-Leu & $26.80 \pm 0.90$ & 0.00851 \\
\hline \multicolumn{4}{c}{ Values are averages of three measurements. }
\end{tabular}

The present study is the first to report the novel ACE-inhibitory peptide Trp-Ala-Ala. To the best of our knowledge, Ala-Trp-Trp and Trp-Leu are the only potent ACE inhibitors that have been identified to occur in a number of protein hydrolysates, for example from hydrolysates of soybean, tofuyo (fermented soybean curd), and salmon. These had $\mathrm{IC}_{50}$ values of 6.5 [54] and 29.9-34.1 $\mu \mathrm{M}[58,59]$, very close to the $\mathrm{IC}_{50}$ value of the purified peptide from PX-5G. However, the Ile-Trp-Trp prepared in this study had a lower the $\mathrm{IC}_{50}$ value than was obtained by Panyayai et al. $(489.14 \mu \mathrm{M})$ [60]. This difference in $\mathrm{IC}_{50}$ values might be because authors used a spectrophotometric method $[44,45,60]$ and a different substrate (furanacryloyl-Lphenylalanylglycylglycine, FAPGG) [61] for their ACE assays. Although other protein hydrolysates have yielded these peptides, no reports have revealed their presence in cobia skin proteins [62-64].

In this study the $\mathrm{IC}_{50}$ values of purified Trp-Ala-Ala and Trp-Leu were higher than those from other peptide sequences. However, a comparison of the $\mathrm{IC}_{50}$ values of Trp-Leu and its reverse sequence showed that the Trp-containing di-peptide at $\mathrm{N}$-terminal residue exhibited lower ACE inhibition. Lower than that of Trp-containing di-peptides at $\mathrm{C}$-terminal-residue with the $\mathrm{IC}_{50}$ values rising from 1.11 to $118.50 \mu \mathrm{M}$, as seen earlier [15]. This is consistent with the findings of Ono et al., with respect to dipeptides and the importance of amino acids at their carboxy terminal [59]. They identified Met-Trp and Trp-Met, different sequences composed of the same amino acid residues, from salmon muscle hydrolysate. The inhibitory activity of Met-Trp $\left(\mathrm{IC}_{50}=9.8 \mu \mathrm{M}\right)$ was 10 times greater than that of Trp-Met $\left(\mathrm{IC}_{50}=98.6 \mu \mathrm{M}\right)$. In some studies, it has been reported that the ACE-inhibition modes of di-peptide pairs (such as, VW, IW, and MW) containing the same amino acid compositions but reversed peptide sequences, were of different types, except for Trp-Leu and Leu-Trp, which were both noncompetitive inhibitors [59]. Some results in the literature indicated that the proper sequence and composition of amino acid residues are crucial in determining the ACE-inhibition mode of the peptides [59]. The Ala-Trp-Trp and Ile-Trp-Trp sequences also showed excellent ACE inhibition. This may have been because the C-terminals all included Trp-containing amino acids. The N-terminal on the other hand were all hydrophobic branched-chain amino acids. This result was similar to that found by He et al. [65]. Wu et al. [66] used Z descriptors in a study of ACE 168 dipeptides and 140 tripeptides with respect to quantitative structure/activity relationship. They found that ACE 
inhibition was influenced to a large extent by three-dimensional chemical properties. Hydrophobic peptides with terminal carboxy amino acids, like tyrosine, tryptophan, and phenylalanine are all know to have very good ACE inhibition. The peptide sequences all agreed with results obtained by Li et al. [67] for systematic induction and those of Cheung et al. [68] with respect to ACE inhibition by peptides. Panyayai et al. [51] also performed molecular docking to elucidate the catalytic pockets of ACE. The results showed that Ile-Trp-Trp could bind to the catalytic pockets of ACE through a network of hydrophobic, electrostatic, and hydrogen bonds with different carboxylic groups of ACE residues. This network could increase its interaction with ACE in a favorable way. Notably, the most advantageous type of each amino acid position in a tripeptide is unique. The preferred residue at the carboxy terminus is an aromatic amino acid, while the intermediate position is a positively charged amino acid, and the amino terminus is preferably a hydrophobic amino acid [66]. However, elucidation of the correlation between the mechanisms of ACE inhibition and the peptide structures await further study.

\section{Conclusions}

Cobia skin was hydrolyzed in Protamex for five hours. The $\mathrm{IC}_{50}$ of the resulting hydrolysate (PX-5) to ACE was $0.221 \mathrm{mg} / \mathrm{mL}$. SHRs were given oral doses of $600 \mathrm{mg}$ of PX-5/kg BW. Four hours after administration, the systolic blood pressure of the experimental SHR group had dropped $21.9 \mathrm{~mm}$ $\mathrm{Hg}$ below than that of the controls and the diastolic blood pressure had dropped to $15.5 \mathrm{~mm} \mathrm{Hg}$ lower than that of the controls. Four peptides from the hydrolysate that showed active ACE inhibition had amino acid sequences of: Trp-Ala-Ala, Ala-Trp-Trp, Ile-Trp-Trp, and Trp-Leu, and IC 50 values of 118.5, 9.4, 0.51 , and $26.8 \mu \mathrm{M}$. The ACE inhibition was present in vitro and clear antihypertensive activity was demonstrated in vivo. This suggested that an ACE-inhibitor could be derived from a cobia skin protein hydrolysate and used to develop functional products that could be used for the prevention of hypertension. This study also provides evidence that the small cobia skin peptides are bioactive and have potential for such applications.

Author Contributions: The experiments were designed by G.-W.C. and Y.-H.L. The laboratory work was done by G.-W.C., Y.-H.L., and C.-A.C. Data was analysed by Y.-H.L., G.-W.C., C.-A.C., and J.-S.T. who also wrote the manuscript. G.-W.C. was responsible for revisions and for supervision of the research.

Funding: This project was funded under grant (NSC96-2313-B-019-012) from the National Science Council, Taiwan. Support was also received from Tan Hou Ocean Develoment Co Ltd.

Conflicts of Interest: None of the authors declares a conflict.

\section{Abbreviations}

PN-5 hydrolysate from Protease N hydrolysis for $5 \mathrm{~h}$

PX-5 hydrolysate from Protamex hydrolysis for $5 \mathrm{~h}$

ACE angiotensin I-converting enzyme

MW molecular weight

SBP systolic blood pressure

DBP diastolic blood pressure

SHRs spontaneously hypertensive rats

BW body weight

RP-HPLC reverse-phase high-performance liquid chromatography

IER inhibitory efficiency ratio

HHL hippuryl- L-histidyl-L-leucine

MWCO molecular weight cut-off

HA hippuric acid 


\section{References}

1. Lopez, A.D.; Murray, C.C. The global burden of disease, 1990-2020. Nat. Med. 1998, 4, 1241-1243. [CrossRef] [PubMed]

2. Yee, S.; Amidon, G.L. Oral absorption of angiotensin-converting enzyme inhibitors and peptide prodrugs. In Peptide-Based Drug Design; Taylor, M.D., Amidon, G.L., Eds.; American Chemistry Society, NW: Washington, DC, USA, 1995; pp. 137-147.

3. Alderman, C.P. Adverse effects of the angiotensin-converting enzyme inhibitors. Ann. Pharmacother. 1996, 30, 55-61. [CrossRef] [PubMed]

4. Al Shohaib, S.; Raweily, E. Acute tubular necrosis due to captopril. Am. J. Nephrol. 2000, 20, 149-152. [CrossRef] [PubMed]

5. Vercruysse, L.; Camp, J.V.; Smagghe, G. ACE inhibitory peptides derived from enzymatic hydrolysates of animal muscle protein: A review. J. Agric. Food Chem. 2005, 53, 8106-8115. [CrossRef] [PubMed]

6. Chen, G.W.; Tsai, J.S.; Sun, P.B. Purification of Angiotensin I-converting enzyme inhibitory peptides and antihypertensive effect of milk produced by protease-facilitated lactic fermentation. Int. Dairy J. 2007, 17, 641-647. [CrossRef]

7. Chen, G.W.; Tsa, J.S.; Sun, P.B. Cardiovascular effects of whey from prozyme 6-facilitated lactic acid bacteria fermentation of milk. J. Food Biochem. 2007, 31, 639-655. [CrossRef]

8. Tsai, J.S.; Chen, T.J.; Pan, B.S.; Gong, S.D.; Chung, M.Y. Antihypertensive effect of bioactive peptides produced by protease-facilitated lactic acid fermentation of milk. Food Chem. 2008, 106, 552-558. [CrossRef]

9. Suetsuna, K. Identification of antihypertensive peptides from peptic digest of the short-necked clam Tapes philippinarum and the pearl oyster Pinctada fucata martensii. Fisheries Sci. 2002, 68, 233-235. [CrossRef]

10. Tsai, J.S.; Chen, J.L.; Pan, B.S. ACE-inhibitory peptides identified from the muscle protein hydrolysate of hard clam (Meretrix lusoria). Process Biochem. 2008, 43, 743-747. [CrossRef]

11. Terashima, M.; Baba, T.; Ikenmoto, N.; Katayama, M.; Morimoto, T.; Matsumura, S. Novel angiotensin-converting enzyme (ACE) inhibitory peptides derived from boneless chicken leg meat. J. Agric. Food Chem. 2010, 58, 7432-7436. [CrossRef]

12. Jahandideh, F.; Majumder, K.; Chakrabarti, S.; Morton, J.S.; Panahi, S.; Kaufman, S.; Davidge, S.T.; Wu, J. Beneficial effects of simulated gastro-intestinal digests of fried egg and its fractions on blood pressure, plasma lipids and oxidative stress in spontaneously hypertensive rats. PLoS ONE 2014, 9, e115006. [CrossRef] [PubMed]

13. Jahandideh, F.; Chakrabarti, S.; Majumder, K.; Li, Q.; Panahi, S.; Morton, J.S.; Davidge, S.T.; Wu, J. Egg white protein hydrolysate reduces blood pressure, improves vascular relaxation and modifies aortic angiotensin II receptors expression in spontaneously hypertensive rats. J. Funct. Foods 2016, 27, 667-673. [CrossRef]

14. Majumder, K.; Wu, J. Purification and characterisation of angiotensin I converting enzyme (ACE) inhibitory peptides derived from enzymatic hydrolysate of ovotransferrin. Food Chem. 2011, 126, 1614-1619. [CrossRef] [PubMed]

15. Majumder, K.; Chakrabarti, S.; Morton, J.S.; Panahi, S.; Kaufman, S.; Davidge, S.T.; Wu, J. Egg-derived tri-peptide IRW exerts antihypertensive effects in spontaneously hypertensive rats. PLoS ONE 2013, 8, e82829. [CrossRef] [PubMed]

16. Majumder, K.; Chakrabarti, S.; Morton, J.S.; Panahi, S.; Kaufman, S.; Davidge, S.T.; Wu, J. Egg-derived ACE-inhibitory peptides IQW and LKP reduce blood pressure in spontaneously hypertensive rats. J. Funct. Foods 2015, 13, 50-60. [CrossRef]

17. Jang, J.H.; Jeong, S.C.; Kim, J.H.; Lee, Y.H.; Ju, Y.C.; Lee, J.S. Characterisation of a new antihypertensiveangiotensin I-converting enzyme inhibitory peptide from Pleurotus cornucopiae. Food Chem. 2011, 127, 412-418. [CrossRef] [PubMed]

18. Suetsuna, K.; Chen, J.R. Identification of antihypertensive peptides from peptic digest of two microalgae, Chlorella vulgaris and Spirulina platensis. Mar. Biotechnol. 2001, 3, 305-309. [CrossRef]

19. Xie, J.; Chen, X.; Wu, J.; Zhang, Y.; Zhou, Y.; Zhang, L.; Tang, Y.J.; Wei, D. Antihypertensive effects, molecular docking study, and isothermal titration calorimetry assay of angiotensin I-converting enzyme inhibitory peptides from Chlorella vulgaris. J. Agric. Food Chem. 2018, 66, 1359-1368. [CrossRef] 
20. Lin, Y.H.; Chen, G.W.; Yeh, C.H.; Song, H.; Tsai, J.S. Purification and identification of angiotensin I-converting enzyme inhibitory peptides and the antihypertensive effect of Chlorella sorokiniana protein hydrolysates. Nutrients 2018, 10, 1397. [CrossRef]

21. Wijesekara, I.; Qian, Z.J.; Ryu, B.; Ngo, D.H.; Kim, S.K. Purification and identification of antihypertensive peptides from seaweed pipefish (Syngnathus schlegeli) muscle protein hydrolysate. Food Res. Int. 2011, 44, 703-707. [CrossRef]

22. Lin, H.C.; Alashi, A.M.; Aluko, R.E.; Sun, P.B.; Chang, Y.W. Antihypertensive properties of tilapia (Oreochromis spp.) frame and skin enzymatic protein hydrolysates. Food Nutr. Res. 2018, 61, 1391666. [CrossRef] [PubMed]

23. Fahmi, A.; Morimura, S.; Guo, H.C.; Shigematsu, T.; Kida, K.; Uemura, Y. Production of angiotensin I converting enzyme inhibitory peptides from sea bream scales. Process Biochem. 2004, 39, 1195-1200. [CrossRef]

24. Byun, H.G.; Kim, S.K. Purification and characterization of angiotensin I converting enzyme (ACE) inhibitory peptides from Alaska pollack (Theragra chalcogramma) skin. Process Biochem. 2001, 36, 1155-1162. [CrossRef]

25. Lin, L.; Shun, L.; Bafang, L. Angiotensin-I-converting enzyme (ACE)-inhibitory and antihypertensive properties of squid skin gelatin hydrolysates. Food Chem. 2012, 131, 225-230. [CrossRef]

26. Alemán, A.; Gómez-Guillén, M.C.; Montero, G. Identification of ace-inhibitory peptides from squid skin collagen after in vitro gastrointestinal digestion. Food Res. Int. 2013, 51, 790-795. [CrossRef]

27. Ngo, D.H.; Vo, T.S.; Ryu, B.M.; Kim, S.K. Angiotensin-I-converting enzyme (ACE) inhibitory peptides from Pacific cod skin gelatin using ultrafiltration membranes. Process Biochem. 2016, 51, 1622-1628. [CrossRef]

28. Yang, P.; Jiang, Y.; Hong, P.; Cao, W. Angiotensin I converting enzyme inhibitory activity and antihypertensive effect in spontaneously hypertensive rats of cobia (Rachycentron canadum) head papain hydrolysate. Food Sci. Technol. Int. 2012, 19, 209-215. [CrossRef] [PubMed]

29. Ditty, J.G.; Shaw, R.F. Larval development, distribution, and ecology of cobia, Rachycentron canadum, (Family: Rachycentridae) in the northern Gulf of Mexico. Fish Bull 1992, 90, 668-677.

30. Liao, I.C.; Huang, S.T.; Tsai, W.S.; Hsueh, M.C.; Chang, L.C.; Leaño, E. Cobia culture in Taiwan: Currents status and problems. Aquaculture 2004, 237, 155-165. [CrossRef]

31. Shih, Y.C. Marine environmental management and development strategy for marine aquaculture in Taiwan: Cobia case study. Ad. Oceanogr. Mar. Biol. 2018, 1, AOMB.MS.ID.000504.

32. Liu, S.C.; Li, D.T.; Hong, P.Z.; Zhang, C.H.; Yang, P.; Ji, H.W. Evaluation of protein nutritional value in different tissues of cobia. Food Sci. Technol. 2009, 35, 158-160. (In Chinese)

33. Kristinsson, H.G.; Rasco, B.A. Biochemical and functional properties of Atlantic salmon (Salmo salar) muscle hydrolyzed with various alkaline proteases. J. Agric. Food Chem. 2000, 48, 657-666. [CrossRef] [PubMed]

34. Shahidi, F.; Han, X.Q.; Synowiecki, J. Production and characteristics of protein hydrolysates from capelin (Mallotus villosus). Food Chem. 1995, 53, 285-293. [CrossRef]

35. Je, J.Y.; Qian, Z.J.; Lee, S.H.; Byun, H.G.; Kim, S.K. Purification and antioxidant properties of bigeye tuna (Thunnus obesus) dark muscle peptide on free radicalmediated oxidative systems. J. Med. Food 2008, 11, 629-637. [CrossRef] [PubMed]

36. Qian, Z.J.; Je, J.Y.; Kim, S.K. Antihypertensive effect of angiotensin I converting enzyme-inhibitory peptide from hydrolysates of bigeye tuna dark muscle, Thunnus obesus. J. Agric. Food Chem. 2007, 55, 8398-8403. [CrossRef] [PubMed]

37. Je, J.Y.; Qian, Z.J.; Byun, H.G.; Kim, S.K. Purification and characterization of an antioxidant peptide obtained from tuna backbone protein by enzymatic hydrolysis. Process Biochem. 2007, 42, 840-846. [CrossRef]

38. Kim, S.K.; Kim, Y.T.; Byun, H.G.; Nam, K.S.; Joo, D.S.; Shahidi, F. Isolation and characterization of antioxidative peptides from gelatin hydrolysate of Allaska Pollack skin. J. Agric. Food Chem. 2001, 49, 1984-1989. [CrossRef]

39. Lee, S.H.; Qian, Z.J.; Kim, S.K. A novel angiotensin I converting enzyme inhibitory peptides from tuna frame protein hydrolysate and its antihypertensive effect in spontaneously hypertensive rats. Food Chem. 2010, 118, 96-102. [CrossRef]

40. Lowry, O.H.; Resebrough, N.J.; Farr, A.L.; Randall, R.J. Protein measurement with the folin phenol reagent. J. Biol. Chem. 1951, 193, 265-275.

41. Cooper, T.G. Spectrophotometry. In The Tools of Biochemistry, 1st ed.; Wiley-Interscience: Hoboken, NJ, USA, 1977; pp. 53-55. ISBN 0471171166. 
42. Church, F.C.; Swaisgood, H.E.; Porter, H.D.; Catignani, G.L. Spectrophotometric assay using $o$-phthaldialdehyde for determination of proteolysis in milk and isolated milk proteins. J. Dairy Sci. 1983, 66, 1219-1227. [CrossRef]

43. Doi, E.; Shibata, D.; Matoba, T. Modified colorimetric ninhydrin methods for peptidase assay. Anal. Biochem. 1981, 118, 173-184. [CrossRef]

44. Cushman, D.W.; Cheung, H.S. Spectrophotometric assay and properties of the angiotensin-converting enzyme of rabbit lung. Biochem. Parmacol. 1971, 20, 1637-1648. [CrossRef]

45. Wu, J.; Ding, X. Characterization of inhibition and stability of soy-protein-derived angiotensin I-converting enzyme inhibitory peptides. Food Res. Int. 2002, 35, 367-375. [CrossRef]

46. Lin, Y.H.; Tsai, J.S.; Chen, G.W. Purification and identification of hypocholesterolemic peptides from freshwater clam hydrolysate with in vitro gastrointestinal digestion. J. Food Biochem. 2017, 41, e12385. [CrossRef]

47. UniProt Database. Available online: http://www.uniprot.org (accessed on 1 January 2019).

48. Pairwise Sequence Alignment Software. Available online: https://www.ebi.ac.uk/Tools/psa/ (accessed on 1 January 2019).

49. SAS Institute Inc. SAS®9.4 TS1M5 User's Guide; SAS Institute Press: Cary, NC, USA, 2019; p. 35.

50. Tsai, J.S.; Lin, T.C.; Chen, J.L.; Pan, B.S. The inhibitory effects of freshwater clam (Corbicula fluminea, Muller) muscle protein hydrolysates on angiotensin I converting enzyme. Process Biochem. 2006, 41, 2276-2281. [CrossRef]

51. Kuba, M.; Shinjo, S.; Yasuda, M. Antihypertensive and hypocholesterolem effects of tofuyo in spontaneously hypertensive rats. J. Health Sci. 2004, 50, 670-673. [CrossRef]

52. Kaiser, S.; Martin, M.; Lunow, D.; Rudolph, S.; Mertten, S.; Möckel, U.; Deußen, A.; Henle, T. Tryptophancontaining dipeptides are bioavailable and inhibit plasma human angiotensin-converting enzyme in vivo. Int. Dairy J. 2016, 52, 107-114. [CrossRef]

53. Ruiz, J.Á.G.; Ramos, M.; Recio, J. Angiotensin converting enzyme inhibitory activity of peptides isolated from Manchego cheese. Stability under simulated gastrointestinal digestion. Int. Dairy J. 2004, 14, 1075-1080. [CrossRef]

54. Gu, R.Z.; Chen, Y.L.; Liu, W.Y.; Yi, W.X.; Cai, M.Y. Angiotensin I-converting enzyme inhibitory activity of low-molecular-weight peptides from Atlantic salmon (Salmo salar L.) skin. Food Res. Int. 2011, 44, 1536-1540. [CrossRef]

55. Lee, J.K.; Jeon, J.K.; Byun, H.G. Antihypertensive effect of novel angiotensin I converting enzyme inhibitory peptide from chum salmon (Oncorhynchus keta) skin in spontaneously hypertensive rats. J. Funct. Foods 2014, 7, 381-389. [CrossRef]

56. Hernández-Ledesma, B.; Contreras, M.M.; Recio, I. Antihypertensive peptides: Production, bioavailability, and incorporation into foods. Adv. Coll. Interface Sci. 2011, 165, 23-35. [CrossRef] [PubMed]

57. Sekiya, S.; Kobayashi, Y.; Kita, E.; Imamura, Y.; Toyama, S. Antihypertensive effects of tryptic hydrolysate of casein on normotensive and hypertensive volunteers. J. Jpn. Soc. Nutr. Food Sci. 1992, 45, 513-517. [CrossRef]

58. Kuba, M.; Tanaka, K.; Tawata, S.; Takeda, Y.; Yasuda, M. Angiotensin I-converting enzyme inhibitory peptides isolated from tofuyo fermented soybean food. Biosci. Biotechnol. Biochem. 2003, 67, 1278-1283. [CrossRef] [PubMed]

59. Ono, S.; Hosokawa, M.; Miyashita, K.; Takahashi, K. Inhibition properties of dipeptides from salmon muscle hydrolysate on angiotensin I-converting enzyme. Int. J. Food Sci. Technol. 2006, 41, 383-386. [CrossRef]

60. Panyayai, T.; Sangsawad, P.; Pacharawongsakda, E.; Sawatdichaikul, O.; Tongsima, S.; Choowongkomon, K. The potential peptides against angiotensin-I converting enzyme through a virtual tripeptide-constructing library. Comput. Biol. Chem. 2018, 77, 207-213. [CrossRef] [PubMed]

61. Henda, Y.B.; Labidi, A.; Arnaudin, I.; Bridiau, N.; Delatouche, R.; Maugard, T.; Piot, J.M.; Sannier, F.; Thiéry, V.; Bordenave-Juchereau, S. Measuring angiotensin-I converting enzyme inhibitory activity by microl plate assays: Comparison using marine cryptides and tentative threshold determinations with captopril and losartan. J. Agric. Food Chem. 2013, 61, 10685-10690. [CrossRef]

62. Balgir, P.P.; Sharma, M. Biopharmaceutical potential of ACE-inhibitory peptides. J. Proteom. Bioinform. 2017, 10, 171-177. [CrossRef]

63. Daskaya-Dikmen, C.; Yucetepe, A.; Karbancioglu-Guler, F.; Daskaya, H.; Ozcelik, B. Angiotensin-I-converting enzyme (ACE)-inhibitory peptides from plants. Nutrients 2017, 9, 316. [CrossRef] 
64. Mora, L.; Gallego, M.; Toldrá, F. ACEI-inhibitory peptides naturally generated in meat and meat products and their health relevance. Nutrients 2018, 10, 1259. [CrossRef]

65. He, R.; Ma, H.; Zhao, W.; Qu, W.; Zhao, J.; Luo, L.; Zhu, W. Modeling the QSAR of ACE-inhibitory peptides with ANN and its applied illustration. Int. J. Pept. 2012. [CrossRef]

66. Wu, J.; Aluko, R.E.; Nakai, S. Structural requirements of angiotensin I-converting enzyme inhibitory peptides: Quantitative structure-activity relationship study of di- and tripeptides. J. Agric. Food Chem. 2006, 54, 732-738. [CrossRef] [PubMed]

67. Li, G.H.; Le, G.W.; Shi, Y.H.; Shrestha, S. Angiotensin-I-converting enzyme inhibitory peptides derived from food proteins and their physiological and pharmacological effects. Nutr. Res. 2004, 24, 469-486. [CrossRef]

68. Cheung, H.S.; Wang, F.L.; Ondetti, M.A.; Sabo, E.F.; Cushman, D.W. Binding of peptide substrates and inhibitors of angiotensin-converting enzyme. J. Biol. Chem. 1980, 255, 401-407. [PubMed]

C 2019 by the authors. Licensee MDPI, Basel, Switzerland. This article is an open access article distributed under the terms and conditions of the Creative Commons Attribution (CC BY) license (http://creativecommons.org/licenses/by/4.0/). 